\title{
THE EFFECTS OF COLONIALISM ON SHARIAH: THE MALACCA AND SOKOTO EXPERIENCES
}

\author{
Alhaji Umar Alkali ${ }^{1}$ \\ Kamal Alhaji Daud ${ }^{2}$
}

\begin{abstract}
Muslims around the world have made a full attempt to ensure that the law of Allah the Most High and Exalted becomes their guidance in all their affairs. Malacca Sultanate and Sokoto Caliphate implemented Shariah before the coming of the colonial masters. When the colonial masters came, they introduced the doctrine of validity to make Islamic law a secondary law especially in criminal matters. Islamic law was made applicable to Muslims only on matters of Muslim personal law such as marriage, divorce and custody of children. Even after independence, not much was seen of Islamic criminal law in these territories. However, a new awakening amongst Muslims has resulted in the implementation of some aspects of Islamic criminal law in Malaysia and Nigeria. Since democracy advocates that the voice of the majority must always be reckoned with, it will therefore not be out of place to have Islamic law in these territories. But that is supposed to hold when machineries for its implementation
\end{abstract}

\footnotetext{
1 PhD Candidate, Ahmad Ibrahim Kulliyyah of Laws, International Islamic University of Malaysia, and Lecturer Faculty of Law, University of Maiduguri, Borno State, Nigeria, umaralka@yahoo.co.uk

2 Lecturer, Faculty of Law, University of Maiduguri, Borno State, Nigeria, kamaldaud2002@yahoo.com
} 
are put in place, sincerity on the part of Muslims is achieved and awareness is created. The article therefore aims to expose the effect of colonialism on Islamic law in Malacca and Sokoto, status of Shariah after independence in Malaysia and Nigeria and suggestions on how to make implementation of Shariah more successful in these territories.

Keywords: Shariah, Malacca Sultanate, Sokoto Caliphate, Colonialism

\section{INTRODUCTION}

History has shown that many parts of the Muslim world have upheld the principles of Shariah in their political, social and economic dealings before the coming of colonialism. It has always been argued that the motive behind colonization includes among other things expansion of territories and economic gains. ${ }^{3}$ Looking at the set back suffered by Shariah due to colonization, one could think that the motive for colonization does not end at just imperial objectives but also extends to attempt to tame the growth and expansion of Shariah in most parts of the world. ${ }^{4}$ This thinking is informed by the fact that almost all Muslim nations have suffered a set back in the implementation and adherence to Shariah or Islamic law upon the coming of the colonial masters. ${ }^{5}$

The principle employed has always been subjecting Islamic law to the validity tests. Meaning, for any principle of Islamic law to apply, it must not be repugnant to natural justice, equity and good conscience. ${ }^{6}$ Surprisingly, there is no parameter to measure the meaning and extent of the use of these tests. In other words, the application of these tests is objective in nature and as such purely subject to the determination of the colonial master. ${ }^{7}$

3 Okene, A.A., 'Sharia Implementation in Democratic Nigeria: Historical Background and the Quest for Developmental Legality,' Journal of Politics and Law 4/2 (2011): 144.

4 Okene, A.A., 'Sharia Implementation in Democratic Nigeria: Historical Background and the Quest for Developmental Legality,' 144.

5 Okene, A.A., 'Sharia Implementation in Democratic Nigeria: Historical Background and the Quest for Developmental Legality,' 144.

6 Alkali, A.U., et al., 'Nature and Sources of Nigerian Legal System: An Exorcism of A Wrong Notion,' International Journal of Business, Economics and Law, 5/4 (2014): 6 .

7 Alkali, A.U., et al., 'Nature and Sources of Nigerian Legal System: An Exorcism of A Wrong Notion.' 
During the Malacca Sultanate ${ }^{8}$ and Sokoto Caliphate, ${ }^{9}$ Islamic law flourished and enjoyed the patronage and respect of the locals. ${ }^{10}$ In fact, Islamic law was seen as part and parcel of the people. Setbacks in the implementation of Islamic law in Malacca and Sokoto started when the colonization process started. ${ }^{11}$ The colonization of Malacca and Sokoto subjected Islamic law and the sultanate itself to be under the control and dictates of the colonial administration. ${ }^{12}$ This paper intends to look at the position of Shariah before, during and after colonialism in the two Sultanates and suggests how implementation of Shariah can be improved.

\section{ISLAMIC LAW DURING THE MALACCA SULTANATE}

Before the coming of Islam, the Malays followed customs and traditions that were significantly influenced by Hindu concept. ${ }^{13}$ Parameswara was the first Malacca ruler to accept Islam after his marriage to the princess Malik Ul-Salih of Pasai. During that period, Islam spread through out the Malacca region. ${ }^{14}$ The love to identify with the rulers' religion made most of the laymen and traders accept Islam. Foreigners equally accepted Islam without compulsion on the part of the ruler. That was because of the Islamic principle that there is no compulsion in religion. ${ }^{15}$ Under Islamic law, a person should be allowed to exert his reason and accept Islam upon conviction of its truth. For those who did not accept Islam, they coexisted peacefully with the locals. Inter marriages between local Malays and foreigners significantly assisted in the spread and acceptance of Islam among foreigners in Malacca; this was because of the feeling of acceptance and peaceful coexistence. ${ }^{16}$ But after the acceptance of

\footnotetext{
8 Presently in Malaysia.

9 Presently in Nigeria.

10 Bidin, A., 'The Historical and Traditional Features of the Malaysian Constitution,' JABET 21 (1993), 3-20, 4.

11 Ziltener, P., and Künzler, D., 'Impacts of Colonialism: A Research Survey,' American Sociological Association, 19/2 (2013): 292.

12 Ziltener, P., and Künzler, D., 'Impacts of Colonialism: A Research Survey,' 292.

13 Bidin, A., 'The Historical and Traditional Features of the Malaysian Constitution,' 4.

14 Yeoh, C.R., 'Malaysia, Truly Asia? Religious Pluralism in Malaysia,' available at www.pluralism.org/research/reportsyeoh/pluralism-malaysia, accessed 14 February 2014.

15 Surah al-Baqarah, 2: 256, states that there is no compulsion in religion.

16 Yeoh, C.R., 'Malaysia, Truly Asia? Religious Pluralism in Malaysia.'
} 
Islam by the Malays, several moves were made to modify and make the Malay traditions conform with Islamic law, for example the Risālah Hukm Qānūn or the Undang-Undang Malacca was amended. ${ }^{17}$ The Shāfi'̄ School of Islamic jurisprudence became the predominant law. ${ }^{18}$

The Malacca sultanate produced a code known as the Hukm Qānūn Malacca (Canons of Malacca). It was the first written law produced by the Sultanate which sets to depart from the customary laws adhered hitherto. The law sets to fuse Islamic principles into 'a dat (customs). The Canon mentioned thus:

"And thus the qānūn has been laid down to punish all wrongful acts in the hope that their perpetrators would be aware of and show sympathy towards the weak and the orphan. "19

The Canons of Malacca, initially compiled under the third ruler dealt with the regulation of commercial matters and a separate codification of maritime laws concentrated specifically on matters concerned with sea going trade. The four syahbandars, or harbour masters were appointed, each one responsible for different ethnic groups. ${ }^{20}$ Their function was more that of policing the affairs of incoming traders; to manage the market place and the warehouse; to maintain a check on instruments of measure and to adjudicate disputes between ship captains and merchants. $^{21}$

The criminal law in the Canon sets to regulate the relations between individual and the state. It promotes peace, harmony and justice in the system. ${ }^{22}$ It sets severe punishment for disobedience to the ruler. ${ }^{23}$ Since the ruler is the most important person in the society he must be obeyed by all his subjects. Obedience to the ruler as set in the Canon is in consonance with Islamic principles. The Quran and traditions of Prophet Muhammad (PBUH) have

17 Fang, L.Y., 'Islamic Law in Malaysia,' Jurnal Undang-Undang(1981): 21, available at http://www.psb1.uum.edu.my/lpBin21/law.dll?f=FifLink\&t=document-frame.h tm\&l=data\&iid=154773c9.691db83a.0.0\&nid=ba, accessed 6 April 2015.

18 Hasan, Z., 'Legal Thoughts of Madhhab al-Shäfi $\bar{l}$ in the Implementation of Islamic Banking In Malaysia,' available at https://zulkiflihasan.files.wordpress. com/2008/05/jurnal-ikim-20061.pdf., accessed 6 April 2015.

19 Johan, K., 'Undang-Undang Melaka (Laws of Melaka),' Royal Asiatic Society LXXII/2 (1999) available at http//:malaysiahistory.net/index, accessed 16 February 2014.

20 Moorthy, R., 'The Evolution of the Chitty Community of Melaka,' JEBAT, 36 (2009): 4.

21 Moorthy, R., 'The Evolution of the Chitty Community of Melaka,' 5.

22 Moorthy, R., 'The Evolution of the Chitty Community of Melaka,' 5.

23 Moorthy, R., 'The Evolution of the Chitty Community of Melaka,' 5. 
mentioned the importance and virtue attached to obedience to the ruler. The Quran states:

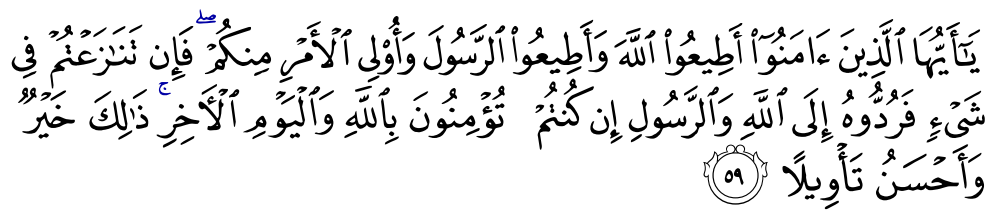

"O ye who believe! Obey God, and obey the Apostle and those charged with authority among you. If ye differ in anything among yourselves, refer it to God and His Apostle, if ye do believe in God and the Last Day: that is best and most suitable for final determination."

(Surah al-Nisā', 4: 59)

The Prophet (PBUH) equally said listen and obey your leader, even if he is a slave. ${ }^{24}$ The Canon of Malacca is no longer applicable especially as it relates to criminal law. With the coming of the colonial masters, English type criminal law with English type judges was applied throughout Malaysia. ${ }^{25}$ The criminal law applied is similar to that applicable in India which was equally a former colony of Britain. ${ }^{26}$ In other words, a law similar to that applicable in India was brought and made applicable in Malaysia by the colonial masters.

With respect to inheritance, before the coming of Islam to Malacca, the ' $\bar{a}$ dat or custom of Sumatera (Minangkabau tribe) was used in the distribution of the estate of a deceased person. ${ }^{27}$ In Minangkabau, a matrineal pattern of inheritance was adopted and that survived for centuries. ${ }^{28}$ After conversion to Islam by the Malays and the establishment of a sultanate, Islamic rules of distribution of estate became the law applicable in Malacca. ${ }^{29}$ However, issues of inheritance are seldom made subject to litigation in Malaysia because it is

24 Abū Dāwūd and al-Tirmithī, available at http://abdurrahman.org/sunnah/ 40hadith nawawi.html, accessed 31 March 2013.

25 Hassan, A.H.M., 'The Administration of Criminal Justice in Malaysia: The Role and Function of Prosecution,' available at http://www.unafei.or.jp/english/pdf/ RS_No53/No53_25PA_Hassan.pdf, accessed 1 April 2015.

26 Hassan, A.H.M., 'The Administration of Criminal Justice in Malaysia: The Role and Function of Prosecution.'

27 Marican, P., Islamic Inheritance Laws in Malaysia, $2^{\text {nd }}$ ed. (Malaysia: Lexis Nexis, 2008), 6.

28 Marican, P., Islamic Inheritance Laws in Malaysia, 6.

29 Marican, P., Islamic Inheritance Laws in Malaysia, 6. 
difficult to find a woman going to court to litigate against her own children or other relatives of the husband on issues relating to inheritance and as such most cases are settled by mutual agreement ${ }^{30}$ which often ends with giving the widow more than the one eighth prescribed by the Shariah. The reason for this is however not unrelated with the custom of the people even before the coming of Islam. ${ }^{31}$ It will therefore not be out of place to submit that traces of the preIslamic traditions are still traceable in the present day Malacca.

\section{ISLAMIC LAW IN MALACCA DURING COLONIALISM}

Islamic law was fully implemented in Malacca before colonialism. ${ }^{32}$ In 1786 , the British arrived in Penang on the threshold of the Industrial revolution that brought new machines and new productivity hence the urge for market and raw materials. ${ }^{33}$ By 1819 , Malacca had also become a colony of Britain. ${ }^{34}$ The British, through a series of treaties with the Sultans of Malacca particularly the Treaty of Pangkor in 1874, established English style courts and English judges which made Islamic law a secondary law that was applicable only to Muslims in limited matters relating to family and inheritance and in some aspects of Islamic offences. ${ }^{35}$ This is in addition to the fact that any decision of the Shariah court can be reversed by the decision of the civil court. ${ }^{36}$ There was not much resistance on the part of the locals towards the colonial occupation of Malaysia due to the feeling that the coming of the colonial administration was more of an opportunity to ban man to man subordination in the form of slavery and oppression of the masses by the ruling class. ${ }^{37}$ The attitude of the colonial masters towards Islamic law however saw reaction by some

30 In Nigeria however, cases of inheritance especially when it relates to large amount often end up in courts. Though the parties are not usually the widow against her children, but rather the widow and her children against other relatives of the deceased.

31 Marican, P., Islamic Inheritance Laws in Malaysia, 8.

32 Hashim A., Rights of Suspect and Accused under Islamic Law and Malaysian Law (Selangor: International Law Book Services, 2004), 21.

33 Hickling R.H., 'The Historical Background to the Malaysian Constitution,' Reflection on The Malaysian Constitution (Malaysia: Persatuan Aliran Kesedaran Negara, 1987), 25.

34 Hickling R.H., 'The Historical Background to the Malaysian Constitution,' 25.

35 Hickling R.H., 'The Historical Background to the Malaysian Constitution,' 25.

36 See Tengku Mariam vs. Commissioner of Religious Affairs (1967) 1 MLJ 10.

37 Hamid, A.F., 'The Impact of British Colonialism on Malaysian Islam: An Imperative Account and the Modern Age,' 37/2, ed. Wasay A. et al. (New Delhi: Zakir Hussain Institute of Islamic Studies Jamia Millia Islamia, 2004), 21. 
pan Islamists towards the colonial administration for instance Dato' Bahaman led the Pahang Rebellion in 1891-1895. ${ }^{38}$ Similarly, Malaysian students in alAzhar University had written against the colonial administration in Seruan Azhar (Voice of Azhar) in $1927 .{ }^{39}$

Though the Malay rulers were allowed to remain as custodians of Islam and the ' $\bar{a} d a t^{40}$ of the Malays, their actions could be reviewed by the British Resident Officer or Adviser. In fact, the law requires that a British Resident's advice must be asked and acted upon on all questions other than those touching on Malay religion and custom. ${ }^{41}$ On the face of it, one could think this requirement of non-consultation on matters touching on Islam and 'a dat as good and maintaining the sanctity of the religion. More so with the restriction imposed on the propagation of Christianity to the Malays except in the strait settlements. This in reality only attempts to introduce secularism into the system where religion and state are treated separately ${ }^{42}$ and a deviation from the very foundation upon which the Malays/Malaccans existed before the coming of colonialism. Looking at the very nature of Islam which is a complete way of life, ${ }^{43}$ any attempt to put a line of demarcation between the affairs of the state and the practice of Islam is undoubtedly a defeat of the very foundation upon which the application of Islamic law stands.

The colonial administration succeeded in entrenching secular ideology from the onset thereby pushing Islamic law into the background. In an effort to achieve this, an attempt was even made to differentiate between Shariah and civil law and to declare that the Shariah is a law meant for Muslims and only concerns the Muslims in matters of personal law. With the Civil Law Enactment of 1937 and its subsequent extension in 1951, English Law was given a solid foundation in Malacca which situation made English Law applicable even on

38 Hamid, A.F., 'The Impact of British Colonialism on Malaysian Islam: An Imperative Account and the Modern Age,' 22.

39 Hamid, A.F., 'The Impact of British Colonialism on Malaysian Islam: An Imperative Account and the Modern Age,' 22.

40 'A $\bar{d}$ dat is an Arabic word which means culture and tradition of the people.

41 Suwannathat-Pian, K., 'British Colonial Rule, Japanese Occupation, and the Transformation of Malay Kinship 1930s-1957,' New Zealand Journal of Asian Studies 11/1 (2009): 109.

42 Hamid, A.F., 'The Impact of British Colonialism on Malaysian Islam: An Imperative Account and the Modern Age,' 25.

43 Islam is an organic whole, a complete way of life that can best be appreciated when practiced completely. See surah al-Hajj, 22: 11. 
matters that affect Muslim personal law. ${ }^{44}$ Until today, the Malay procedure of marriage and divorce has been described as a mixture of Muslim law, 'ádat and statute law. ${ }^{45}$

As Malaysia was on the verge of independence, the issue of Islam was one of the hotly deliberated issues. In 1957 there was in place the Draft Reid Constitution which was borrowed mostly from the Indian Constitution. ${ }^{46}$ The recommendations of the Reid Commission was received, amended and finally adopted by the Crown, Malay rulers and the elected government. ${ }^{47}$ It will therefore be safe to say that the present Malaysian Constitution is a development of the Independence Constitution of 1957 which grew out of the Federal Agreement of 1948. It has elements of Malay origin (making the Yang di Pertuan Agong the ruler), declaring Islam as state religion, ideas of WestMinister and experience of India to form a unique Constitution. ${ }^{48}$ The Reid Commission Report states that:

"There was universal agreement that... (a provision on state
religion) ...were inserted. It must be clear that it will not in any
way affect the civil rights of the non-Muslims. In the memorandum
submitted by the alliance, it was stated "the religion of Malaysia
shall be Islam." The observance of this principle shall not impose
any disability on non-Muslim natives professing and practicing
their religions and shall not imply that the state is not a secular
state." 49

Article 3 of the Constitution states that Islam is the religion of the Federation but other religions may practice in peace and harmony in any part of the Federation. The wordings of the Constitution are clear to the effect that Islam is the religion of the state, but is that enough for one to assert that Malaysia is an Islamic state? The attitude of the courts headed by English trained judges is tilted towards the position that Malaysia is not an Islamic state but a secular

44 Hamid, A.F., 'The Impact of British Colonialism on Malaysian Islam: An Imperative Account and the Modern Age,' 25.

45 Hamid, A.F., 'The Impact of British Colonialism on Malaysian Islam: An Imperative Account and the Modern Age,' 25.

46 Ibrahim, A., The Malaysian Legal System (Malaysia: Penerbit Fajar Bakti Sdn. Bhd., 2003), 87.

47 Bari, A., Malaysian Constitution: A Critical Introduction (Kuala Lumpur: The Other Press, 2003), 46.

48 Bari, A., Malaysian Constitution: A Critical Introduction, 46.

49 Bari, A. \& Shuaib, F.S., Constitution of Malaysia Text and Commentary (Malaysia: Pearson Prentice Hall, 2004), 5. 
state. ${ }^{50}$ Similarly, the reality on ground does not support the view that Malaysia is an Islamic state (though it is a matter of interpretation). ${ }^{51}$ However, there are provisions for constitutional amendment which could be followed to make the position unambiguous that Malaysia is an Islamic state and non-Muslims have the right to practice their religion without interference and within the confines of the law.

In the present day of Malaysia, Shariah courts have jurisdiction over both civil and criminal matters. ${ }^{52}$ With respect to Criminal Jurisdiction, the Shariah Courts (Criminal Jurisdiction) Act 1965, have restricted the jurisdiction of Shariah courts in criminal cases only to Muslims ${ }^{53}$ and relating to offences such as gambling, intoxication, adultery, fornication, khalwat, ${ }^{54}$ ill-treatment of wife, disobedience of wife, non-payment of zakāh and disrespect for Ramadān. ${ }^{55}$

The courts have however insisted that Islamic Law in Malaysia is part and parcel of the people. It has evolved over time and remained the law applicable to the Malays before the coming of the colonial masters and even after they have left. To treat Islamic law as a foreign law is therefore unacceptable and

$50 \quad$ In Che Omar bin Che Soh vs. Public Prosecutor [1988] 2 MLJ 55 and Teoh Eng Huat vs. Kadhi of Pasir Mas, Kelantan and Majlis Ugama Islam dan Adat Istiadat Melayu Kelantan [1990] 2 MLJ 306, the courts maintained the view that Malaysia is not an Islamic State but a secular state. Similarly, in Lina Joy vs. Majlis Agama Islam Wilayah Persekutuan \& 2 Ors 2005 [CA] and Meor Atiqulrahman Ishak vs. Fatimah binti Sihi [2000] 5 MLJ 375, issues of right to religious freedom were addressed and the decisions favoured the argument that Malaysia is a secular State.

51 Bari, A., Malaysian Constitution: A Critical Introduction, 46.

52 9th Schedule, State List, List II. The criminal jurisdiction of Shariah Courts in Malaysia is conferred by the Shariah Courts (Criminal Jurisdiction) Act 1965, see also Jusoh, H., The Position of Islamic Law in The Malaysian Constitution with Special Reference to The Conversion Case in Family Law (Kuala Lumpur: Dewan Bahasa dan Pustaka, 1991).

53 Section 2, Shariah Courts (Criminal Jurisdiction) Act 1965.

54 Khalwat is an Arabic word which means seclusion. In other words, it is an offence that occurs when a person goes into close proximity with a person of the opposite sex (not being within the prohibited degrees of consanguinity and affinity) in a suspicious manner. It is punishable under section 27 (a) and (b) of the Shariah Criminal Offences (Federal territories) Act.

55 Shuaib, F.S., et al., Administration of Islamic Law in Malaysia Text and Material (Kuala Lumpur: Butterworths Asia, 2010), 200. 
must be rejected. In Sheikh Abd-Latif Other vs. Sheikh Elias Bux, ${ }^{56}$ Braddel C.J. said:

"Before the first treaties the population of these states consisted almost solely of Mohammadan Malays with large industrial and mining Chinese in their midst. The only law that was applicable to the Malays was Mohammadan modified by local custom."

Similarly in Ramah vs. Laton, ${ }^{57}$ the Court of Appeal held that Muslim law is not foreign law but local law and the law of the land. The court must take judicial notice of it and must propound the law. The Islamic re-awakening experienced in Malaysia today with a call for modernity and the crave to realizing the vision 2020 which sets to achieve a modern Malaysia that is connected with its Islamic origin ${ }^{58}$ is not unconnected with the history of the Malays where Islamic law was accepted, respected and enforced in Malacca.

\section{SHARIAH IN NIGERIA BEFORE COLONIALISM}

Before the coming of the colonial masters to Nigeria, ${ }^{59}$ its people lived as independent and to some extent unrelated entities with different cultures and beliefs. ${ }^{60}$ Since the task of this subheading is to look at Shariah in Nigeria before colonialism, it is worthy to mention that Shariah in Nigeria before colonialism is basically divided into three regions. Sokoto Caliphate, ${ }^{61}$ Kanem

56 Sheikh Abd-Latif Other vs. Sheikh Elias Bux [1915] 1 FMSLR 204.

57 Ramah vs. Laton [1927] 6 FMSCR 127.

58 Othman N., 'The Sociopolitical Dimensions of Islamisation in Malaysia: A Cultural Accommodation of Social Changes?' in Sharia Law and The Modern -State A Malaysian Symposium, ed. Othman, N. (Malaysia: SIS Forum, 1998), 140.

59 Great Britain was the colonial master of Nigeria, contact between Nigeria and Britain started with trading and subsequently graduated to colonization. The southern part of the country was the first to come into contact with Britain before the Northern part of the country. That is not unconnected with its proximity to the Atlantic Ocean.

60 For example the north has the Muslim majority, while Islam was equally found in the south west (Yoruba Land) and the south east were into idol worshiping.

${ }_{61}$ Otherwise referred to as Hausa land, because the Sokoto $j i h \bar{a} d$ was waged against the Hausa kings (Habes) by the predominantly Fulani Muslims. 
Borno Empire ${ }^{62}$ and Yoruba Land. ${ }^{63}$ Practically, Shariah is more pronounced in the northern part of Nigeria as it is seen in both private and public lives of its people. This section will however be focused on Shariah in Sokoto Caliphate (Hausa Land) because it was the largest and strongest of all the Shariah practicing territories in Nigeria.

At present, Hausa Land is located in the central Bilād al-Sudān ${ }^{64}$ and it shares a common border with kanem Borno in the east and Songhai in the west. ${ }^{65}$ The Hausa land was at a point in history under the political control of Kanem Borno and Songhai. ${ }^{66}$ Prior to the coming of Islam into Hausa Land, the Hausa people toiled under a variety of pagan beliefs. Though each community has its type of belief depending on its peculiarities, they share a common ideology of the existence of a high distant god (ubangiji) who has supernatural forces that support him (iskoki) who are directly in touch with the people. And human agents (bokaye) that serve as intermediary between god and the people. They were believed to have the powers to bless the community with bumper harvest or even deny this and subject the individual or community to hardship or relief. ${ }^{67}$ There is no consensus opinion as to when Islam arrived in Hausa Land. ${ }^{6}$ However, records reveal that Islam arrived in Hausa Land in the fourteenth century through the instrumentality of the Arab traders who were involved in the trans-Sahara trade. ${ }^{69}$ The Arab or Muslim traders came along

62 Kanem Borno was the first emirate or region to come into contact with Islam and its rulers (mais) accepted Islam and made Shariah the way of life centuries before the Hausa jihād started. Available at htpp://www.playahata.com/page/bhfigures/ bhfigures22.html, accessed 20 March 2014.

63 Though there is significant presence of Muslims in Yoruba land, there was however idol worship to a great extent in the region. However some aspects of Shariah were practiced by the Yorubas. See Aliyu, B., 'Practical Approach to the Harmonisation of Sharia and Civil Law: A Critical Analysis of the Nigerian Experience,' www. academia.edu/207313, accessed 19 March 2014.

64 Bilād al-Sudān is an Arabic expression which literally means the land of the blacks.

65 Sulieman, I., A Revolution in History: The Jihad of Usman Dan Fodio (London: Mansell Publishing Limited, (ND)), 46. Available at www.nmfuk.org/danfodio/ IbrahimSulieman'sBooks.pdf, accessed 28 February 2014.

66 Sulieman, I., A Revolution in History: The Jihad of Usman Dan Fodio, 46.

67 Sulieman, I., A Revolution in History: The Jihad of Usman Dan Fodio, 46.

68 Fagge, T.A, Introduction, Spread and Development of Islam in Kano Since 1350 A.D., available at www.kano.line.com/jmqs/index.php, accessed 6 March 2014.

69 Fagge, T.A, Introduction, Spread and Development of Islam in Kano Since 1350 A.D., accessed 6 March 2014. 
with their belief and due to their honesty in dealing and good manners; the locals accepted the belief (Islam) of the traders. ${ }^{70}$

Though most of Hausa Land practiced Islam before the jihäd of Usman Dan-Fodio, ${ }^{71}$ elements of disbelief (shirk) were seen in every aspect of the daily life of the Hausa people. ${ }^{72}$ Records indicated that Islam was accepted in Hausa Land as early as $11^{\text {th }}$ Century. Sheikh Muhammad Maghali an Islamic cleric, teacher and missionary who came from Borno ${ }^{73}$ is believed to have converted the king of Daura to Islam. ${ }^{74} \mathrm{He}$ stayed in Daura and strengthened Islam and then moved to Kano. Though Islam was already established in Kano, he succeeded in establishing Islamic schools, built mosques and created a conducive atmosphere for the spread and practice of Islam before leaving Kano. $^{75}$

\section{THE SOKOTO JIH $\bar{A} D$}

The brain behind the Sokoto jih $\bar{a} d$ is Shehu Usman Ibn Fodio ${ }^{76}$ who was born in 1754 in the town of Maratta presently in Nigeria ${ }^{77}$ to a family of well mannered

70 Some however argue that the coming of Islam to Hausa Land is not limited to one route or to one group.

71 Aremu, J.O., 'The Fulani Jihad and its Implication for National Integration and Development in Nigeria,' An International Multidisciplinary Journal, Ethiopia, 5/5 (2011): 3 .

72 Aremu, J.O., 'The Fulani Jihad and its Implication for National Integration and Development in Nigeria,' 3.

73 Aremu, J.O., 'The Fulani Jihad and its Implication for National Integration and Development in Nigeria,' 3.

74 Aremu, J.O., 'The Fulani Jihad and its Implication for National Integration and Development in Nigeria,' 4.

75 Aremu, J.O., 'The Fulani Jihad and its Implication for National Integration and Development in Nigeria,' 4.

76 His full name is Uthman bn Muhammad bn Uthman bn Salih bn Ayyub bn Harun bn Muhammad Gordo bn Muhammad Jabbo bn Muhammad Sambo bn Ayyub bn Bubab Bani bn Masiran bn Ayyub bn Musa also known as Jakolo who came from Futa Toro. The name Foduye is his father's epithet, which is a Fulfulde (the tribe of the Shehu) word meaning "the learned" and the word "Dan" means son of in Hausa language. His family migrated from Futa Toro to Hausa Land in the 5th Century after Hijra. Islahi, A.Z., 'Usman Dan Fodio and His Economic Ideas,' available at http://mpra.ub.uni-muenchen.de/40916/1/Economic_Ideas_of_Shehu_Othman Dan_Fodio.pdf, accessed 1 April 2015.

77 Islahi, A.Z., 'Usman Dan Fodio and His Economic Ideas.' 
scholars. ${ }^{78}$ His parents moved shortly to Degal shortly after his birth and that was where Shehu was brought up. ${ }^{79}$ Shehu studied the Glorious Quran from his father and acquired other Islamic knowledge from many scholars. ${ }^{80}$ His character was initially molded by Usman Bidduri and Muhammad Sambo who set Shehu on the path of pity, patience and call on the path of Allah ${ }^{81}$ which served as the backbone of his call to Allah. Shehu Jibrin Ibn Umar was one who influenced the Sheikh the most. Shehu followed him to Agedes, where taught Shehu many things including the Qādiriyya order, ${ }^{82}$ and introduced the Shehu to the idea of tajdid and he was the first to pledge alliance with the Shehu even before the commencement of the jihäd. After succeeding in his $j i h \bar{a} d$, the Shehu moved from Sifawa to Sokoto in $1814-1815 .{ }^{83}$ In 1812, the Shehu handed over the responsibility of running the caliphate to Abdullahi and Bello ${ }^{84}$ and the Shehu finally passed away on 20 April $1817 .{ }^{85}$

Several factors were responsible for sparking the jihād against the Hausa Emirs by Shehu Uthman. ${ }^{86}$ Though the Emirs have professed Islam, in practice

78 His father's name is Muhammad Ibn Salih generally knows as Ibn Fodio and his mothers name is Hauwa Bint Muhammad Ibn Usman.

79 Sulieman, I., A Revolution in History: The Jihad of Usman Dan Fodio, 21.

80 Such as Ahmad Ibn Muhammad al-Amin, Al-Haj Muhammad Ibn Raj, Sheikh AlMadani, Abu al-Hassin Ali etc. Sulieman, I., A Revolution in History: The Jihad of Usman Dan Fodio, 21

81 Sulieman, I., A Revolution in History: The Jihad of Usman Dan Fodio, 21.

82 Qādiriyya is a Sufi order which was founded by Sheikh Abdul Qādir Jilani who died 1166 C.E. in Baghdad, Iraq. The main ideology of the Sufis of the Qädiriyah order is to lay great stress on the purification of the self. The Sufis maintained that the human soul came from the world of command and is capable of reflecting the Divine Light, but due to impurities of the self, it does not do so. If a mirror becomes rusty it cannot reflect any form placed before it, but when the rust is removed, it begins to reflect clearly. Thus if the mirror of the heart is clean, the beauty of the Beloved (Allah) reflects in it and one can see this in the personality of the seeker, inwardly and outwardly. See Conway, T., Muslim Sūfĩ Shaikh 'Abd al-Qādir al-Jīlānī (1077-1166 AD), 'Sultan of the Saints', available at http://www. enlightened-spirituality.org/support-files/sufism_qadir_al_jilani.pdf., accessed 1 April 2015.

83 Sulieman, I., A Revolution in History: The Jihad of Usman Dan Fodio, 56.

84 Sulieman, I., A Revolution in History: The Jihad of Usman Dan Fodio, 152.

85 Sulieman, I., A Revolution in History: The Jihad of Usman Dan Fodio, 156.

86 Bugaje, U.M., The Sokkwato Model: A Study of The Origin, Development and Fruition of The Jihad of Uthman b. Fodio (1754-1817) (Sokoto: Nizamiyya Islamiyya School, 1980), 16. 
they combined traditional idol worship with Islam known as bori. ${ }^{87}$ The Shehu categorized people generally into three, the first group constitute those who believed in Allah and practiced true Islam without bringing acts of disbelief in their day to day activities. For this category of people, no war will be waged against them ${ }^{88}$ and in fact they are the people of the Shehu. The second group constitute disbelievers (kuffär bi al-asal) this were people who worshipped idols and had not in any way believed or practiced Islam and as such jihäd will be wedged against them. ${ }^{89}$ While the third group were unbelievers by syncretism (kuffär bi takhlit). ${ }^{90}$ Though they were seen to have professed Islam by words, their actions however led them to disbelief because they combined Islam with the worship of idols and other non-Islamic practices in their daily affairs. Most parts of Hausa land fall under this category and as such waging

87 Ige, J., 'The Ideals of Sokoto Caliphate in The Outlying Districts: The Okun Factor in The British Conquest of Northern Nigeria, 1897-1906,' in Sokoto Caliphate: History and Legacies, 1804-2004 vol. 1, ed. Bobboy, H., and Yakubu, A.M. (Kaduna: Arewa House, 2004), 14.

88 Under Islamic Law, a Muslim is not allowed to take the life of another Muslim except in accordance with the rule of Shariah and any person who wages war against Muslims without the sanction of the Quran and Hadith earns for himself the anger and wrath of Allah. The Quran states in surah al-Nisā' 4:92, "Never should a believer kill another believer; but (if it happens) by mistake (compensation is due): if one so kills a believer, it is ordained that he should free a believing slave, and pay compensation to the deceased family, unless they remit it freely. If the deceased belonged to a people at war with you, and he was a believer. The freeing of a believing slave (is enough). If he belonged to a people with whom you have a treaty of mutual alliance, compensation should be paid to his family and a believing slave be freed. For those who find this beyond their means (is prescribed) fast for two month running: by way of repentance to God: for God hath knowledge and all wisdom."

89 The Prophet (PBUH) waged war against the Quraysh who were pagans and were all out to fight the Prophet (PBUH) and his companions and to bury the light of Islam. But there is no consensus opinion among Muslim jurists as to when a jihād could be waged against unbelievers. Some opined that such war could be waged against them only in self defense. Hence Muslims are only allowed to fight unbelievers if the unbelievers attacked them. While others hold that Muslims are allowed to wage jihād to spread the words of Allah. See Arlandson, J.M., 'Illegal Jihad in the Quran and Early Islam,' at http://www.answering-islam.com, accessed 20 March 2014.

90 After the death of the Prophet, the village Arabs decided not to pay zakāh claiming that it is not obligatory, despite the fact that they professed Islam, Sayyidina Abu Bakar fought them and brought them back to the right order. Available at www. islamic-world.net/khalifa/khalifa_ur_rashiduun1.htm, accessed 20 March 2013. 
jihād on them was lawful..$^{91}$ Similarly, there was increasing levels of violence, exploitation by the ruling classes and the enslavement of Muslims etc. ${ }^{92}$

The Shehu then started an underground work for enlightening his people on the evil of the pagan practices done by the pagan Hausas and engineered a revolution then towards Islamic monotheism. ${ }^{93}$ This campaign succeeded and the Shehu had a large amount of followers who believed in his ideology and vowed to support and fight in the cause. ${ }^{94}$ Shehu and his followers did not spark violence against the Hausa Emirs at first. ${ }^{95}$ It was rather the Emirs that tortured and killed the Shehu's followers. In 1804, a Gobir force actually attacked and killed several members of the Shehu that finally led to the declaration of an Islamic state and war on Gobir. The jiha $\bar{d} d$ was the last instrument adopted by the Shehu and he believed that it was necessary if any meaningful result was to be achieved and that it is sanctioned by the Glorious Quran. Though the Shehu has said that the territory of the jihād is Hausa land, the jihād had subsequently found expression in territories outside Hausa land. ${ }^{96}$

When the jihād succeeded Shehu established a real Islamic state with full political powers and all the requirements expected of an Islamic state. ${ }^{97}$ Shariah was apparent in both private and public life of the people. Shehu as spiritual and political leader was highly respected and obeyed because he professed Islam in words and practice. ${ }^{98}$ Educational reforms and transformation of law

91 Sanusi, L.S., Al-Kanemi Before Dan Fodio's Court available at www. nigerdeltacongress.com/articles/alkanemi-between-danfidio-court-htm, accessed 2 March 2014.

92 Robinson, D., 'Revolutions in the Western Sudan,' in the History of Islam in Africa, ed. Levitzion and Powels (Athens: Ohio University Press, 1993), 133.

93 Bugaje, U.M., The Sokkwato Model: A Study of the Origin, Development and Fruition of the Jihad of Uthman b. Fodio (1754-1817), 8.

94 Bugaje, U.M., The Sokkwato Model: A Study of the Origin, Development and Fruition of The Jihad of Uthman b. Fodio (1754-1817), 8.

95 Smith M.G., 'The Jihad of Shehu Usman Dan Fodio: Some Problems,' in Islam in Tropical Africa, ed. Lewis, I.M. (London: Oxford University Press, 1966), 415.

96 Nigeria Usman-Danfodio and The Sokoto Caliphate available at http://www. mongabay.com/history/nigeria /nigeria-/colonial_nigeria.html, 19 March 2014.

97 An Islamic state is a state where sovereignty belongs to Allah, the law of the state is based on the Quran and Hadīth, shüra (consultation) is pronounced in state matters, obedience to the ruler, equal opportunity for all and justice in all matters. See Famous Theories of an Islamic State, at http://www.rubikh.wordpress .com/ tag/the-characteristic-of-an-islamic-state, accessed 19 March 2014.

98 Bugaje, U.M., The Sokkwato Model: A Study of the Origin, Development and Fruition of The Jihad of Uthman b. Fodio (1754-1817), 8. 
were put into place. Literary revival with production of religious work and vernacular written in Arabic script was equally revived by the Shehu. ${ }^{99}$

\section{ISLAMIC LAW IN SOKOTO DURING COLONIALISM}

After the death of Shehu, those who came after him introduced practices that were contrary to the teachings of the Shariah. ${ }^{100}$ By 1885, the intention of the British to take over Sokoto Caliphate was clearly viewed, ${ }^{101}$ though as early as 1885 the British was into a treaty with Sokoto and Gwandu ${ }^{102}$ that was not colonization in reality. Conquest of Sokoto by Frederick Lugard, (appointed a high commissioner of the protectorate of Northern Nigeria) systematically subdued local resistance with his Royal West African Frontier Force (RWAFF). He mounted assault on Kano and Sokoto in 1903 and captured both. British introduced indirect rule thereby using the Emirs to rule, the Sultanate was converted into a lower layer of the colonial bureaucracy. ${ }^{103}$

A dual system of law was introduced, while Islamic law court continued dealing with matters of Islamic personal law subject to the validity tests. ${ }^{104}$ That continued up to the period when Nigeria's independence approached, at which point the colonial masters planned to finally depose Islamic criminal law. The northern Muslims were persuaded to accept the change, and were hence provided a new criminal law that has some Islamic law flavour that resulted in the promulgation of the Penal Code and Criminal Procedure Code. These laws contain most of the offences under Islamic law such as adultery, incest, alcoholism, theft, armed robbery etc but do not actually represent the actual punishment under the Shariah.

Even after independence, Islamic law was perceived as part of customary law and as such subject to validity tests reflected under Section 14(3) of

99 Bugaje, U.M., The Sokkwato Model: A Study of the Origin, Development and Fruition of The Jihad of Uthman b. Fodio (1754-1817), 8.

100 Hirshfield, C., The Diplomacy of Partition: Britain, France and the Creation of Nigeria 1890/1898 (Hague: Martinus Nijhoff, 1979), 39.

101 Hirshfield, C., The Diplomacy of Partition: Britain, France and the Creation of Nigeria 1890/1898, 39.

102 That was actually to pave way for the actual conquest when the time comes.

103 Ochonu, M., 'Village' Democracy and Development in Dutse, Nigeria,' GEFAME Journal of African Studies 7/1 (2010), 7.

104 Ostien, P., \& Fwatshak, S., 'The Settlement of 1960 and Why it Matters Today,' at www.sharia-im-africa.net/media/publications/sharia, accessed 3 March 2014. 
the Evidence Act. ${ }^{105}$ In Adesubekun vs. Yunusa Rasaki ${ }^{106}$ the court held that Islamic law will not apply because it was contrary to Section 3 of the Wills Act. However, recent developments have indicated that the courts have shifted from the notion of regarding Islamic law as part of customary law. For example Justice Wali observed in the case of Alkamawa vs. Bello ${ }^{107}$ that Islamic law is not the same as customary law because it does not belong to any particular tribe.

The Nigerian Constitution has recognized Islamic law through the establishment of Shariah Courts of Appeal thus giving them jurisdiction on matters of Islamic personal law. ${ }^{108}$ Though the Constitution has prohibited the adoption of any religion as a state religion, ${ }^{109}$ it has however guaranteed the right of religion to every citizen of Nigeria ${ }^{110}$ and which by extension means the right of Muslims to practice every aspect of the Shariah. The result thereof was agitation for Islamic criminal law by Muslims, ${ }^{111}$ this earnest call led to the promulgation of Sharia Penal Code in Zamfara State in 2002. ${ }^{112}$

\section{CONCLUSION}

The discussion has made clear the fact that Malacca Sultanate and Sokoto Caliphate have much in common in terms of the history of the evolution of Islamic law and the fate of Shariah during and after colonialism. Since Muslims are the majority in the two domains and they both exist under a democratic government where the voice of the majority is always the determinant factor on what law should apply, it will therefore be right to suggest that Islamic law should be fully implemented in both civil and criminal aspects of the lives of Muslims. Similarly awareness campaigns should be done to make people

105 See also Sections 34 (1) of the High Court Laws Northern Nigeria and 27 (1) of the High Court Laws of Lagos State.

106 Adesubekun vs. Yunusa Rasaki (1977) NNLR 71.

107 Alkamawa vs. Bello (1998) 6 SCNJ 1272.

108 Sections 260, 262, 275 and 277 of the 1999 Constitution FRN.

109 Section 10 of the 1999 Constitution FRN.

110 Section 38 of the 1999 Constitution FRN.

111 Shariah Debates in Africa available at www.sharia-in-africa.net., accessed 22 March 2014. Section 4 (6) of the 1999 Constitution FRN has given the State Houses of Assembly the power to make laws for their states which includes promulgation of Shariah Criminal Laws.

112 Zamfara State is one of the states in northern Nigeria that is coincidentally very close to Sokoto State where Shehu Usman himself died. 
appreciate the beauty and justice in Islamic law, so that the wrong notion that Islamic law is all about stoning to death and amputation will be changed. Equally important is sincerity and patience on the part of Muslims when it comes to challenges to be faced when Islamic law is to be implemented because nonMuslims amongst the citizens and the western world will definitely oppose and strive to frustrate the process.

\section{REFERENCES}

Aliyu, B., 'Practical Approach to The Harmonisation of Sharia and Civil Law- A Critical Analysis of The Nigerian Experience,' www.academia. edu/207313, accessed 19 March 2014.

Alkali, A.U., et al., 'Nature and Sources of Nigerian Legal System: An Exorcism of A Wrong Notion,' International Journal of Business, Economics and Law, 5/4 (2014).

Aremu, J.O., 'The Fulani Jihad and its Implication for National Integration and Development in Nigeria,' An International Multidisciplinary Journal, Ethiopia, 5/5 (2011).

Arlandson, J.M., 'Illegal Jihad in the Quran and Early Islam,' http://www. answering-islam.com, accessed 20 March 2014.

Art and Life in Africa, www.uiowa.edu/my, accessed 16 February 2014.

Bari, A. Malaysian Constitution: A Critical Introduction (Kuala Lumpur: The Other Press, 2003).

Bari, A. \& Shuaib, F.S., Constitution of Malaysia Text and Commentary (Malaysia: Pearson Prentice Hall, 2004).

Bidin, A., 'The Historical and Traditional Features of the Malaysian Constitution,' JABET 21 (1993).

Bugaje, U.M., The Sokkwato Model: A Study of the Origin, Development and Fruition of the Jihad of Uthman b. Fodio (1754-1817) (Sokoto: Nizāmiyya Islāmiyya School, 1980).

Chuks, B.U., 'Repugnancy Doctrine and Customary Law in Nigeria: A Positive Aspect of British Colonialism,' at afrrevjo.net/journals/multidiscipline/ Vol_2_num_2_art_1, accessed 13 February 2014.

Conway, T., Muslim Sūfì Shaikh 'Abd al-Qādir al-J̄̄iānī (1077-1166 AD), 'Sultan of the Saints,' available at http://www.enlightened-spirituality. org/support-files/sufism_qadir_al_jilani.pdf., accessed 1 April 2015.

Fagge, T.A, 'Introduction, Spread and Development of Islam in Kano Since 1350 A.D.,' www.kano.line.com/jmqs/index.php, accessed 6 March 2014. 
Fang, L.Y., 'Islamic Law in Malaysia,' Jurnal Undang-Undang (1981): 21, available at http://www.psb1.uum.edu.my/lpBin21/law.dll?f= FifLink \&t=document-frame.htm\&l=data\&iid=154773c9.691 db83a.0.0 \&nid=ba, accessed 6 April 2015.

Hamid, A.F., 'The Impact of British Colonialism on Malaysian Islam: An Imperative Account and the Modern Age,' et al. (ed.) Wasay A. 37/2 (New Delhi: Zakir Hussain Institute of Islamic Studies Jamia Millia Islamia, 2004).

Hasan, Z., 'Legal Thoughts of Madhhab al-Shāfi' $i$ in the Implementation of Islamic Banking In Malaysia,' available at https://zulkiflihasan.files. wordpress.com/2008/05/jurnal-ikim-20061.pdf., accessed 6 April 2015.

Hashim A., Rights of Suspect and Accused Under Islamic Law and Malaysian Law (Selangor: International Law Book Services, 2004).

Hassan, A.H.M., 'The Administration of Criminal Justice in Malaysia: The Role and Function of Prosecution,' available at http://www.unafei.or.jp/ english/pdf/RS_No53/No53_25PA_Hassan.pdf, accessed 1 April 2015.

Hickling R.H., 'The Historical Background to the Malaysian Constitution,' in Reflection on the Malaysian Constitution (Malaysia: Persatuan Aliran Kesedaran Negara, 1987).

Hirshfield, C., The Diplomacy of Partition: Britain, France and the Creation of Nigeria 1890/1898 (Hague: Martinus Nijhoff, 1979).

Ibrahim, A., The Malaysian Legal System (Malaysia: Penerbit Fajar Bakti Sdn. Bhd., 2003).

Ige, J., 'The Ideals of Sokoto Caliphate in the Outlying Districts: The Okun Factor in the British Conquest of Northern Nigeria, 1897-1906,' in Sokoto Caliphate: History and Legacies, 1804-2004 vol. 1, ed. Bobboy, H., and Yakubu, A.M. (Kaduna: Arewa House, 2004).

Islahi, A.Z. 'Usman Dan Fodio and His Economic Ideas,' available at http:// mpra.ub.uni-muenchen.de/40916/1/Economic_Ideas_of_Shehu Othman_Dan_Fodio.pdf, accessed 1 April 2015.

Johan, K., 'Undang-Undang Melaka (Laws of Melaka),' Royal Asiatic Society, LXXII/2 (1999), http//:malaysiahistory.net/index, accessed 16 February 2014.

Jusoh, H., The Position of Islamic Law in the Malaysian Constitution with Special Reference to The Conversion Case in Family Law (Kuala Lumpur: Dewan Bahasa dan Pustaka, 1991).

Marican, P., Islamic Inheritance Laws in Malaysia, 2n ed. (Malaysia: Lexis Nexis, 2008). 
Metz, H.P. 'Nigeria Usman-Danfodio and The Sokoto Caliphate,' at http:// www.mongabay.com /history/nigeria/nigeria-/colonial_nigeria.html, accessed 19 March 2014.

Ochonu, M., 'Village Democracy and Development in Dutse, Nigeria,' GEFAME Journal of African Studies 7/1 (2010).

Okene, A.A., 'Sharia Implementation in Democratic Nigeria: Historical Background and The Quest for Developmental Legality,' Journal of Politics and Law 4/2 (2011).

Ostien, P., and Fwatshak, S., 'The Settlement of 1960 and Why it Matters Today,' at www.sharia-im-africa.net/media/publications/sharia, accessed 3 March 2014.

Othman N., 'The Sociopolitical Dimensions of Islamisation in Malaysia: A Cultural Accommodation of Social Changes?' in Sharia Law and the Modern-State A Malaysian Symposium, ed. Othman, N. (Malaysia: SIS Forum, 1998).

Robinson, D., 'Revolutions in the Western Sudan,' in The History of Islam in Africa, ed. Levitzion and Powels (Athens: Ohio University Press, 1993).

Sanusi, L.S., 'Al-Kanemi Before Dan Fodio's Court,' www.nigerdelta congress.com/articles /alkanemi-between-danfidio-court-htm, accessed 2 March 2014.

Shuaib, F.S., et al., Administration of Islamic Law in Malaysia Text and Material (Kuala Lumpur: Butterworths Asia, 2010).

Smith M.G., 'The Jihad of Shehu Usman Dan Fodio: Some Problems,' in Islam in Tropical Africa, ed. Lewis, I.M. (London: Oxford University Press, 1966).

Sulieman, I., A Revolution in History: The Jihad of Usman Dan Fodio, (London: Mansell Publishing Limited, n.d.).

Suwannathat-Pian, K., 'British Colonial Rule, Japanese Occupation, and the Transformation of Malay Kinship 1930s-1957,' New Zealand Journal of Asian Studies 11 (2009).

Yeoh, C.R., 'Malaysia, Truly Asia? Religious Pluralism in Malaysia,' http:// www.pluralism.org/research/reportsyeoh/pluralism-malaysia, accessed 14 February 2014.

Ziltener, P., and Künzler, D., 'Impacts of Colonialism: A Research Survey,' American Sociological Association, 19/2 (2013). 


\section{Statutes}

Federal Constitution Republic of Nigeria (FRN) 1999.

Shariah Courts (Criminal Jurisdiction) Act 1965.

\section{Cases}

Adesubekun vs. Yunusa Rasaki [1977] NNLR 71.

Alkamawa vs. Bello [1998] 6 SCNJ 1272.

Che Omar bin Che Soh vs. Public Prosecutor [1988] 2 MLJ 55.

Lina Joy vs. Majlis Agama Islam Wilayah Persekutuan \& 2 Ors 2005 [CA].

Meor Atiqulrahman Ishak vs. Fatimah binti Sihi [2000] 5 MLJ 375.

Ramah vs. Laton [1927] 6 FMSCR 127.

Sheikh Abd-Latif Other vs. Sheikh Elias Bux [1915] 1 FMSLR 204.

Tengku Mariam vs. Commissioner of Religious Affairs [1967] 1 MLJ 10.

Teoh Eng Huat vs. Kadhi of Paris Mas, Kelantan and Majlis Ugama Islam dan Adat Istiadat Melayu Kelantan [1990] 2 MLJ 306. 
Jurnal Syariah, Jil. 23, Bil. 1 (2015) 167-188 